\title{
Assessment of Age Effect of Dumpsite on Biodegradability and Pollution Potentials of
} Leachate

\author{
*1 Badejo A. A., ${ }^{1}$ Adekunle A. A., ${ }^{2}$ Adeosun J. O. and ${ }^{1}$ Nwosu E. G. \\ ${ }^{1}$ Civil Engineering Department, Federal University of Agriculture Abeokuta, Ogun state, Nigeria \\ ${ }^{2}$ Agric and Bio- resources Engineering Department, Federal University of Agriculture Abeokuta, Ogun state, Nigeria \\ *Corresponding e-mail: badejoaa@funaab.edu.ng
}

\section{Abstract}

DOI: 10.36108/laujoces/0202/40(0160)

The increase in world's population has led to increase in waste generation and is a source of concern for stakeholders across the world. These wastes end up in dumpsites which undergo different stages of decomposition thereby producing Leachate which have a tendency of polluting groundwater. This study assessed biodegradability and Leachate Pollution Index (LPI) of dumpsite relative to its age. Three dumpsites Orile $(O)$, Solous $3\left(S_{3}\right)$ and Solous $1\left(S_{1}\right)$ dumpsites with different ages: - less than 5, between 5-10 and greater than 10 years old respectively were studied. Leachate samples were collected from each dumpsite; Physico-chemical parameters: $\mathrm{pH}$, chloride, Iron, Zinc, Arsenic, Total nitrogen, Chemical Oxygen Demand (COD), Biochemical Oxygen Demand (BOD 5 ), Total Dissolved Solid, Electricity Conductivity and heavy metal: Lead, Chromium and Copper were analysed to determine the LPI while BOD $/$ /COD was determined to ascertain the level of biodegradability of the dumpsites. The $B O D_{5} / C O D$ results for $O, S_{3}$ and $S_{1}$ leachates were in the decreasing order of 0.37, 0.29 and 0.21 respectively while LPI results for: $O, S_{1}$ and $S_{3}$ leachate were 10.00, 11.20 and 15.68 respectively which were above the standard limit of 7.38 . The results showed that $O$ and $S_{1}$ dumpsite leachate had least and highest sign of biodegradability respectively. The LPI result showed that $O$ and $S_{1}$ dumpsite leachates had the highest and the least pollution potentials respectively. Leachate from dumpsites less than 5 years has higher pollution potentials and lesser biodegradable than leachates from dumpsites more than 5 years. Leachate from $O$ dumpsite will impact negatively on groundwater quality than leachates from $S_{1}$ and $S_{3}$ dumpsites. The age of a dumpsite leachate determines its pollution potential and biodegradability.

Keywords: Leachate, dumpsite, pollution, biodegradability and solid waste

\section{Introduction}

Dumpsites are organized or illegitimate means of solid waste disposal in land depression such as abandoned quarries, excavations or valleys (Clark, 2006). According to El-Fadel et al. (2005) dumpsites are widely the most used method of waste disposal in the world in comparison to others such as incineration, recycling etc. In most developing countries of low and medium income, almost $100 \%$ of the waste generated goes to dumpsite (Longe and Balogun, 2010). Dumpsites are generally grouped into open dumpsite, controlled dumpsite (engineering landfill) and sanitary dumpsite (engineered landfill).

Dumpsite undergoes phases of decomposition over time, depending on the type of the materials on it. The decomposition occurs under the prevailing influence of climatic conditions and affects the materials differently depending on the quality of the deposits (Barlaz et. al., 1991; Ohman, 1991; Perrson, 1996).

The initial anaerobic phase starts immediately the waste is dumped and is a short period depending on the climate. Degradation of waste starts before disposal at the dumpsite, the biodegradable solid 
waste reacts with oxygen in the dumpsite to form water and carbon dioxide. The temperature at this stage is about $16.7^{\circ} \mathrm{C}$ (Ostman et al., 2006).

At the acidic anaerobic phase, sulphate $\left(\mathrm{SO}_{4}\right)$ is reduced and hydrogen sulphide $\left(\mathrm{H}_{2} \mathrm{~S}\right)$ is produced. The $\mathrm{pH}$ of the leachate is around 5 and at this stage the metal leaching is at its peak.

Oxygen is not required at this stage to breakdown the waste into hydrogen, ammonia, carbon dioxide and organic acid (Ostman et. al., 2006). The Methane phase includes the transformation of acetic acid, carbon dioxide and hydrogen into methane by bacteria that are strictly aerobic. Half of the gas produced is methane while half is carbon dioxide.

The breakdown of degradable organic material in the dumpsite leads to formation of leachate which marks the beginning of humic phase (Barlaz et. al., 1991). The leachate which accumulates at the bottom of unlined dumpsite and contains heavy metals, organic and inorganic compounds percolates into the groundwater and this poses risk to the groundwater quality (Adewole, 2009). The organic strength of leachate expressed in terms of $\mathrm{BOD}_{5} / \mathrm{COD}$ determines the level of biodegradability of a dumpsite leachate. It is necessary to know the variations that occur in the leachate due to biodegradation of MSW and how it impacts on ground water quality.

The LPI is a technique used to determine the pollution potential of dumpsite leachate in a comparative scale. It ranges between 5 and 100 with a standard value of 7.38 ; any value above 7.38 implies that the dumpsite requires attention in terms of remediation measures. The study is therefore aimed at assessing the pollution potentials of three selected dumpsite leachate in Lagos, Nigeria.

\section{Materials and Methods}

The 3 different dumpsites considered in this work were in the age range of less than 5 years and more than 10 years $\left(\mathrm{O}\right.$; less than 5 years, $\mathrm{S}_{1}$; between $5-10$ years and $\mathrm{S}_{3}$; above 10 years) which depicts young, intermediate and old dumpsites respectively according to Chain and Dewale, 1976). The $S_{1}$ dumpsite (fig. 1) is located in Igando, beside Material Recovery Facility in Alimosho Local Government Area of Lagos State. It started operation on February 1996 and covers a total area of 2.9 hectares with a life span of 10 years. It receives average of 10,000 tons of waste per week (LAWMA, 2011). It is a non engineered, low lying, controlled open dumpsite which lies within the latitude $6^{0} 57^{\prime} 17^{\prime} ' \mathrm{~N}$ and longitude $3^{0} 25^{\prime} 28^{\prime \prime} \mathrm{E}$. It has neither bottom liner nor leachate collection and treatment system. The leachates generated find its path into groundwater and surrounding environment.

The $\mathrm{S}_{3}$ dumpsite (Figure 2) is also located in Igando between the General hospital and mini Water Works in Alimosho Local Government Area of Lagos State. It is an open controlled dumpsite which lies between latitude $6^{0} 33^{\prime} 54^{\prime} \mathrm{N}$ and longitude $3^{\circ} 15^{\prime} 4{ }^{\prime \prime} \mathrm{E}$. It started operation in July, 2008 and covers a total area of 10.4 hectares with an average of 6,000 tons of waste per week (LAWMA, 2011). The dumpsite has no protective lining thereby allowing the percolation of leachate into groundwater. The wastes are dumped without segregation but they are compacted in layers to reduce the volume. It receives unprocessed wastes which range from organic to inorganic. Scavengers are always seen around looking for materials to be recycled or reused. 
Volume 4, Issue 1; March, 2020.

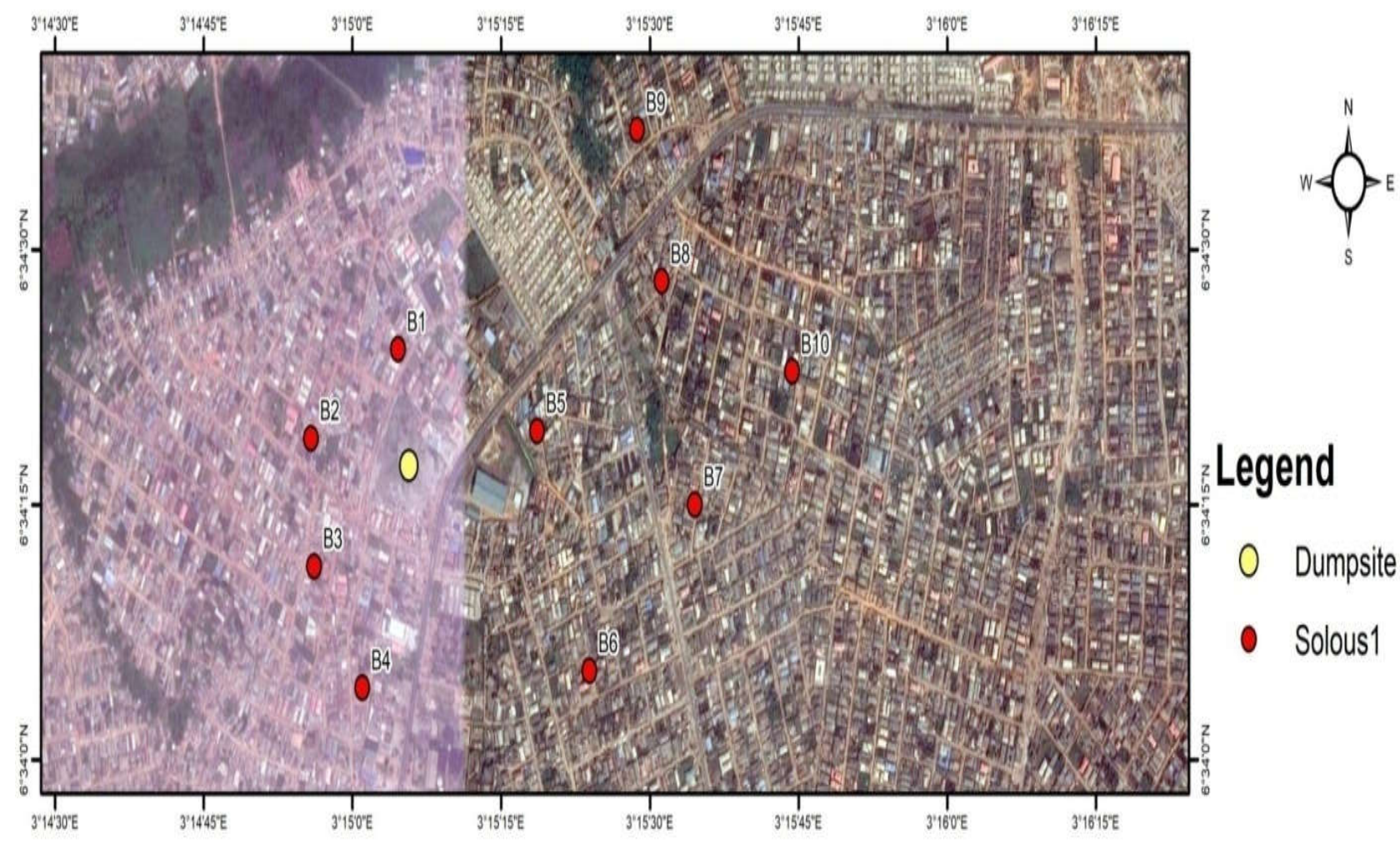

Figure 1: $\mathrm{S}_{1}$ dumpsite

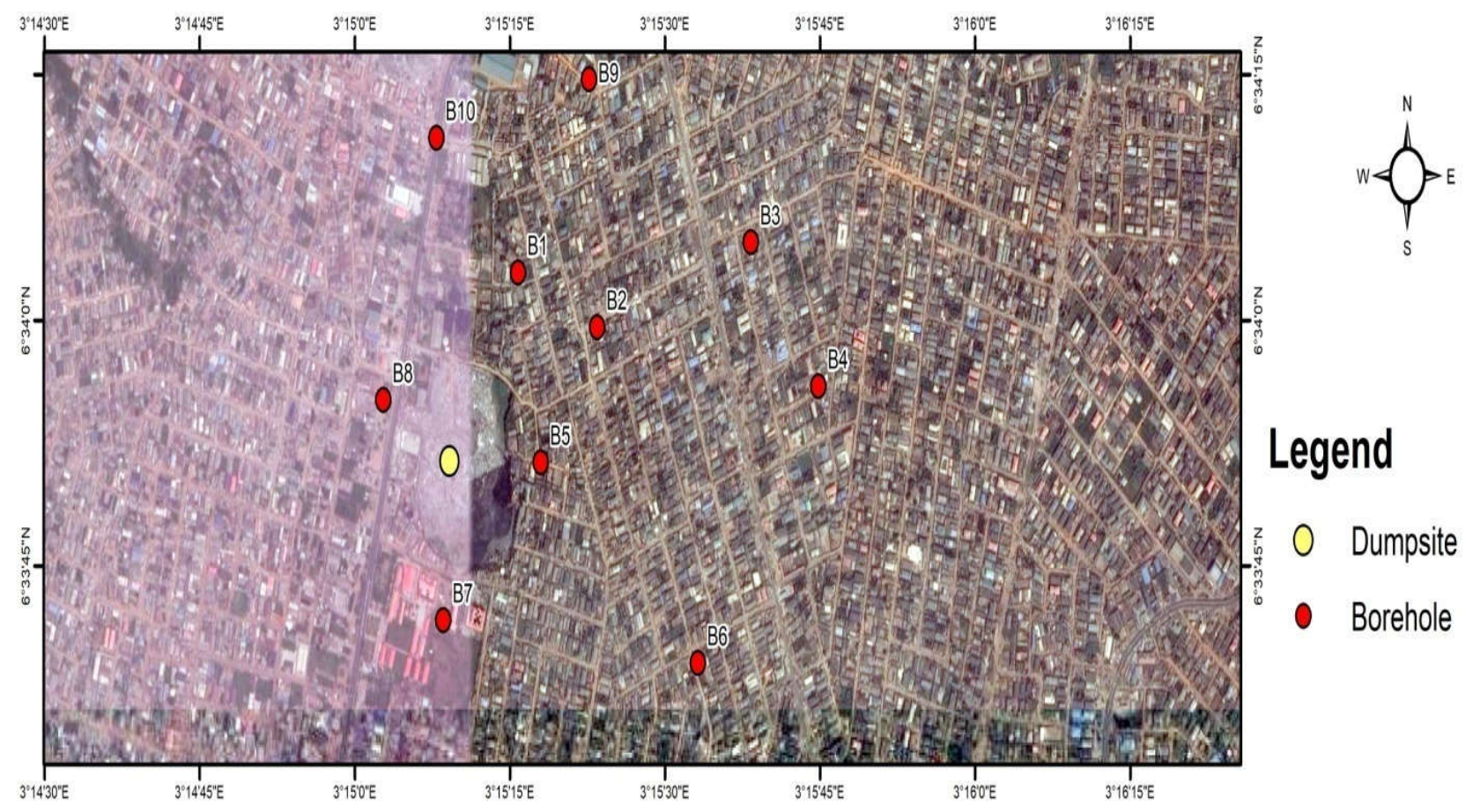

Figure 2: $\mathrm{S}_{3}$ dumpsite 
Orile dumpsite (Figure 3) is an open dumpsite which lies within Latitude $6^{\circ} 28^{\prime} 42^{\prime \prime} \mathrm{N}$ and Longitude $3^{\circ} 20^{\prime} 46^{\prime \prime E}$. It is located opposite Doyin bus stop and beside Orile steel market and at the back of fruit market; it started operation August 2013. The dumpsite receives more of organic materials because it is located near a fruit market. It has no protective lining that inhibits the percolation of leachates into groundwater and the wastes are not being compacted.

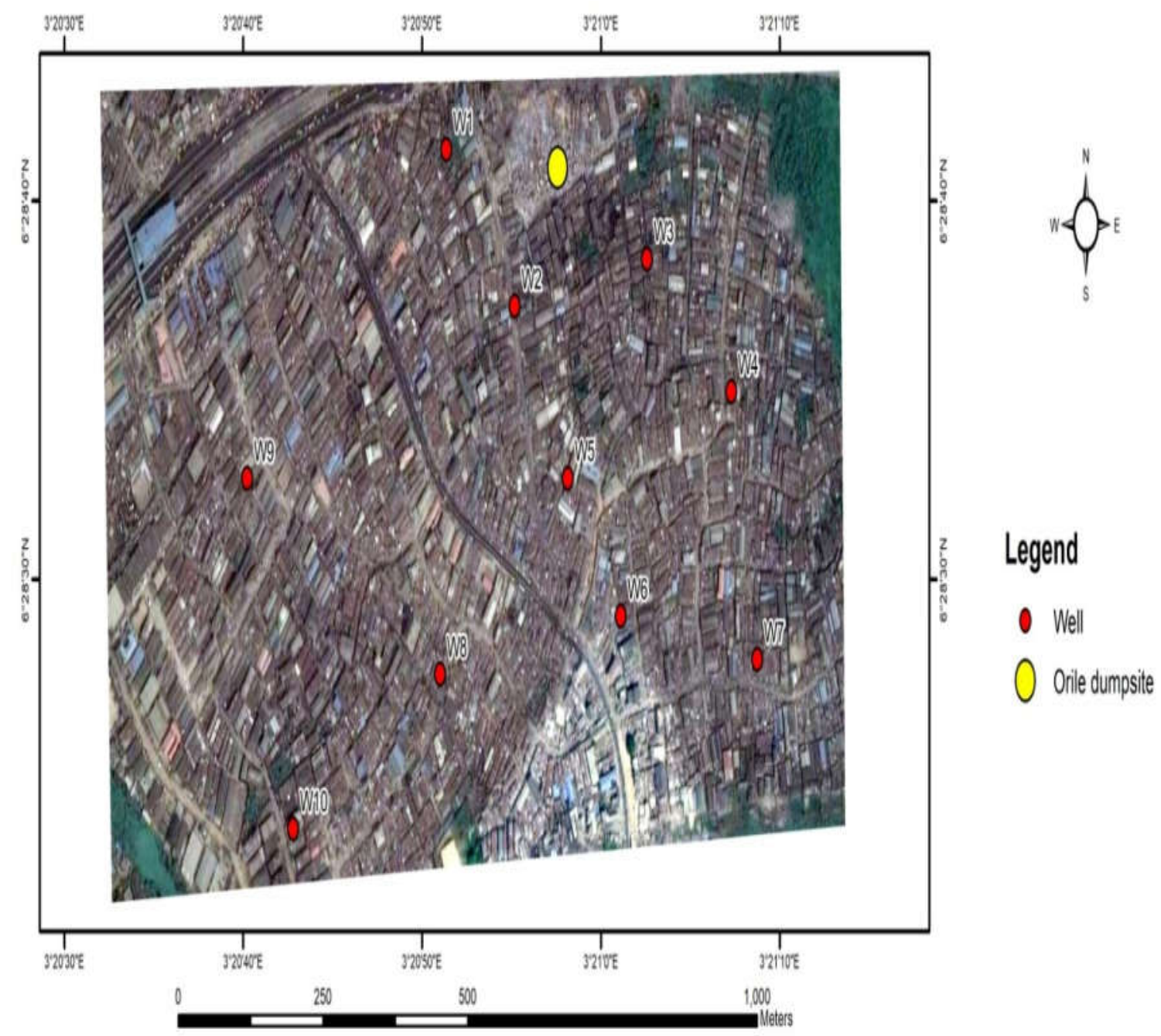

Figure 3: O dumpsite

\section{Sampling and analysis}

Leachate samples were collected from the base of the waste heaps where the leachates drained out under gravity. The coordinates of collection points were $\mathrm{S}_{1}$; longitude of $3^{0} 26^{\prime} 02^{\prime \prime} \mathrm{E}$ and latitude $6^{0} 57^{\prime} 09^{\prime \prime} \mathrm{N}, \mathrm{S}_{3}$; longitude of $3^{0} 25^{\prime} 60^{\prime \prime} \mathrm{E}$ and latitude of $6^{0} 57^{\prime \prime} 18^{\prime \prime} \mathrm{N}, \mathrm{O}$; longitude of $3^{0} 34^{\prime} 58^{\prime \prime} \mathrm{E}$ and latitude of $6^{0} 47^{\prime \prime} 80^{\prime \prime} \mathrm{N}$. The samples were collected in a 1.5 liters plastic container, labeled accordingly and stored in an iced cooler. The samples were transported to Chemistry Laboratory of the University of Lagos the same day for analysis using standard method (APHA, 2005). Heavy Metals were analyzed with Atomic Absorption Spectrophotometer (AAS) (Perkin Elmer Analyst 
Volume 4, Issue 1; March, 2020.

200). The Organic strength of the leachate which ascertains the level of biodegradability of each dumpsite was determined by the $\mathrm{BOD}_{5} / \mathrm{COD}$ relationship

The Leachate Pollution Index (LPI) was computed by determining the pollutant parameters weight (Wi) and the concentration of the pollutant parameters. The pollutant sub index value (Pi) was deduced from a sub index curve. The pollutant rating was determined as a product of pollutant weight (Wi) and pollutant sub index value (Pi).

The LPI of pollutant parameters less than 18 was calculated using:

$$
\mathrm{LPI}=\frac{\Sigma W i P i}{\Sigma W i}
$$

Where

LPI = Leachate Pollutant Index

$\mathrm{Wi}=$ Pollutant weight

$\mathrm{Pi}=\mathrm{Sub}$ index value

\section{Results and Discussions}

The results which showed the age effect on biodegradability and pollution potentials of dumpsites leachates are as presented below:

\section{Biochemical Oxygen Demand (BOD5)/Chemical Oxygen Demand (COD)}

The result of the biodegradability of $\mathrm{S}_{1}, \mathrm{~S}_{3}$ and $\mathrm{O}$ dumpsite expressed in terms $\mathrm{BOD}_{5} / \mathrm{COD}$ as presented in table 1 below shows that $\mathrm{O}$ dumpsite with the highest value is less biodegradable and most unstable compared to $\mathrm{S}_{1}$ and $\mathrm{S}_{3}$. This agrees with results opined by Barjinder et. al., (2012) of $0.24,0.20$ and $0.19 \mathrm{mg} / 1$ for dumpsites within the age range of $0-5$ years, $5-10$ years and 10 years above respectively.

Table 1: Biodegradability of the dumpsite's leachates

\begin{tabular}{lllll}
\hline $\mathrm{S} / \mathrm{N}$ & Parameters & $\mathrm{S}_{1}(>10 \mathrm{yrs})$ & $\mathrm{S}_{3}(5-10 \mathrm{yrs})$ & $\mathrm{O}(<5 \mathrm{yrs})$ \\
\hline 1 & BOD $_{5}$ & 10.21 & 146.30 & 197.29 \\
2 & $\mathrm{COD}$ & 47.04 & 498.69 & 532.29 \\
3 & $\mathrm{BOD} / \mathrm{COD}$ & 0.21 & 0.29 & 0.37 \\
\hline
\end{tabular}

The $\mathrm{BOD}_{5}$ leachate value from $\mathrm{O}, \mathrm{S}_{3}$ and $\mathrm{S}_{1}$ dumpsite were $197.29,146.03$ and $10.21 \mathrm{mg} / 1$ respectively. This is not in agreement with Zainol et. al., (2012) for young leachate (less than 5 years) and old leachate (more than 5 years). The $\mathrm{BOD}_{5}$ leachate values from $\mathrm{O}$ dumpsite and $\mathrm{S}_{3}$ dumpsite were above the Federal ministry of environment limit of $30 \mathrm{mg} / \mathrm{l}$ while that from $\mathrm{S}_{1}$ is less than the limit.

The COD is the measure of amount of oxygen required to completely oxidize chemically the organic waste constituents to inorganic end products in a given mass of leachate sample. The leachate COD value for $\mathrm{O}, \mathrm{S}_{3}$ and $\mathrm{S}_{1}$ dumpsite were $532.68,498.64$ and $40.33 \mathrm{mg} / 1$ respectively. The value of COD from $\mathrm{O}$ and $\mathrm{S}_{3}$ dumpsite were above the limit of Federal Ministry of Environment $75 \mathrm{mg} / \mathrm{l}$. This also shows that $S_{1}$ is at stable methanogenic phase while $O$ and $S_{3}$ are at anaerobic acid phase. 
Tables 2, 3 and 4 showed the Leachate Pollutant concentrations and rating of $\mathrm{S}_{1}, \mathrm{~S}_{3}$ and $\mathrm{O}$ dumpsites.

Table 2: Leachate Pollutants Concentration and Rating for Solous 1

\begin{tabular}{|c|c|c|c|c|c|}
\hline S/no & $\begin{array}{l}\text { Leachate pollutant } \\
\text { parameter }\end{array}$ & $\begin{array}{l}\text { Pollutant } \\
\text { weight } \\
\text { (wi) }\end{array}$ & $\begin{array}{l}\text { Pollutant } \\
\text { concentration } \\
(\mathrm{mg} / \mathrm{l})\end{array}$ & $\begin{array}{l}\text { Pollutant } \\
\text { sub index value } \\
\text { (Pi) }\end{array}$ & $\begin{array}{l}\text { Pollutant rating } \\
\text { (wiPi) }\end{array}$ \\
\hline 1 & $\mathrm{pH}$ & 0.055 & 9.020 & 4.00 & 0.220 \\
\hline 2 & TDS & 0.050 & 5015.27 & 10.00 & 0.500 \\
\hline 3 & $\mathrm{Cl}$ & 0.048 & 29.90 & 5.00 & 2.400 \\
\hline 4 & $\mathrm{SO}_{4}$ & - & 325.70 & - & - \\
\hline 5 & $\mathrm{Cr}$ & 0.064 & 0.05 & 5.00 & 0.320 \\
\hline 6 & $\mathrm{Cu}$ & 0.050 & 0.13 & 5.00 & 0.250 \\
\hline 7 & $\mathrm{Fe}$ & 0.045 & 0.44 & 5.00 & 0.250 \\
\hline 8 & $\mathrm{~Pb}$ & 0.063 & 0.32 & 5.00 & 0.225 \\
\hline 9 & $\mathrm{Zn}$ & 0.056 & 2.75 & 5.00 & 0.280 \\
\hline 10 & As & 0.061 & 0.02 & 5.00 & 0.305 \\
\hline 11 & $\mathrm{BOD}_{5}$ & 0.061 & 76.76 & 6.50 & 0.397 \\
\hline 12 & COD & 0.062 & 847.07 & 10.00 & 0.625 \\
\hline 13 & Total Cyanide & 0.058 & 0.05 & 5.00 & 0.270 \\
\hline 14 & $\begin{array}{l}\text { Total ammonium } \\
\text { nitrate }\end{array}$ & 0.051 & 917.07 & 35.00 & 1.785 \\
\hline 15 & Total nitrogen & 0.050 & 305.69 & 3.30 & 0.615 \\
\hline 16 & Coliform bacteria & 0.052 & $4.4 \times 10^{4}$ & 95.00 & 2.375 \\
\hline
\end{tabular}

Table 3: Leachate Pollutants Concentration and Rating for Solous 3

\begin{tabular}{llllll}
\hline & $\begin{array}{l}\text { Leachate pollutant } \\
\text { parameter }\end{array}$ & $\begin{array}{l}\text { Pollutant } \\
\text { weight } \\
\text { (wi) }\end{array}$ & $\begin{array}{l}\text { Pollutant } \\
\text { concentration } \\
\text { (mg/l) }\end{array}$ & $\begin{array}{l}\text { Pollutant } \\
\text { sub index } \\
\text { value (Pi) }\end{array}$ & $\begin{array}{l}\text { Pollutant rating } \\
\text { (wiPi) }\end{array}$ \\
\hline 1 & $\mathrm{pH}$ & 0.055 & 7.90 & 3.0 & 0.165 \\
2 & $\mathrm{TDS}$ & 0.050 & $11,945.77$ & 17.5 & 0.875 \\
3 & $\mathrm{Cl}$ & 0.048 & 14.99 & 5.0 & 0.240 \\
4 & $\mathrm{SO}_{4}$ & - & 301.50 & - & - \\
5 & $\mathrm{Cr}$ & 0.064 & 0.03 & 5.0 & 0.270 \\
6 & $\mathrm{Cu}$ & 0.050 & 0.02 & 5.0 & 0.025 \\
7 & $\mathrm{Fe}$ & 0.045 & 0.49 & 5.0 & 0.225 \\
8 & $\mathrm{~Pb}$ & 0.063 & 0.30 & 5.0 & 0.315 \\
9 & $\mathrm{Zn}$ & 0.056 & 2.80 & 3.0 & 0.168 \\
10 & $\mathrm{As}$ & 0.061 & 0.02 & 4.0 & 0.244 \\
11 & $\mathrm{BOD}$ & 0.061 & 146.30 & 5.0 & 0.305 \\
12 & $\mathrm{COD}$ & 0.062 & 498.64 & 5.0 & 0.310 \\
13 & Total Cyanide & 0.058 & 0.57 & 5.0 & 0.290 \\
14 & Total ammonium & 0.051 & 1455.69 & 20.0 & 1.020 \\
& nitrate & & & & \\
& & & & & \\
15 & Total nitrogen & 0.050 & 485.23 & 40.0 & 2.000 \\
16 & Coliform bacteria & 0.052 & $4.40 \times 10^{4}$ & 55.0 & 2.860 \\
& & & & \\
\hline
\end{tabular}


Table 4: Leachate Pollutants Concentration and Rating for Orile dumpsite

\begin{tabular}{llllll}
\hline S/No & $\begin{array}{l}\text { Leachate pollutant } \\
\text { parameter }\end{array}$ & $\begin{array}{l}\text { Pollutant weight } \\
\text { (wi) }\end{array}$ & $\begin{array}{l}\text { Pollutant } \\
\text { concentration } \\
(\mathrm{mg} / \mathrm{l})\end{array}$ & $\begin{array}{l}\text { Pollutant } \\
\text { sub index } \\
\text { value (Pi) }\end{array}$ & $\begin{array}{l}\text { Pollutant rating } \\
\text { (wiPi) }\end{array}$ \\
\hline 1 & $\mathrm{pH}$ & 0.055 & 4.500 & 5.0 & 0.275 \\
2 & $\mathrm{TDS}$ & 0.050 & 909.000 & 8.0 & 0.400 \\
3 & $\mathrm{Cl}$ & 0.048 & 183.840 & 5.0 & 0.240 \\
4 & $\mathrm{SO}_{4}$ & - & 960.000 & - & - \\
5 & $\mathrm{Cr}$ & 0.064 & 0.032 & 5.0 & 0.027 \\
6 & $\mathrm{Cu}$ & 0.050 & 0.516 & 9.0 & 0.030 \\
7 & $\mathrm{Fe}$ & 0.045 & 0.418 & 5.0 & 0.225 \\
8 & $\mathrm{~Pb}$ & 0.063 & 0.090 & 5.0 & 0.315 \\
9 & $\mathrm{Zn}$ & 0.056 & 3.730 & 5.0 & 0.280 \\
10 & $\mathrm{As}$ & 0.061 & 0.500 & 10.0 & 0.610 \\
11 & $\mathrm{BOD} 5$ & 0.061 & 197.290 & 5.0 & 0.305 \\
12 & $\mathrm{COD}$ & 0.062 & 532.280 & 5.0 & 0.310 \\
13 & Total Cyanide & 0.058 & 0.950 & 15.0 & 0.870 \\
14 & Total ammonium & 0.051 & 5.890 & 35.0 & 1.785 \\
& nitrate & & & & \\
15 & Total nitrogen & 0.050 & 1.960 & 45.0 & 2.250 \\
& & & $1.940 \times 10^{4}$ & 100.0 & 5.200 \\
\hline
\end{tabular}

\section{Leachate pollution index (LPI) of dumpsites}

The value of LPI for $\mathrm{O}, \mathrm{S}_{3}$ and $\mathrm{S}_{1}$ dumpsites were $15.86,11.20$ and 10.00 respectively as shown in Figure 5. The normal LPI value that will pose no threat to groundwater quality according to Kumar and Allapat (2005) is 7.38. This result shows that $\mathrm{O}$ dumpsite which is young (less than 5 years) has more pollution potential than $S_{3}$ and $S_{1}$ dumpsites which are intermediate (between 5 10 years) and old (more than 10 years) respectively.

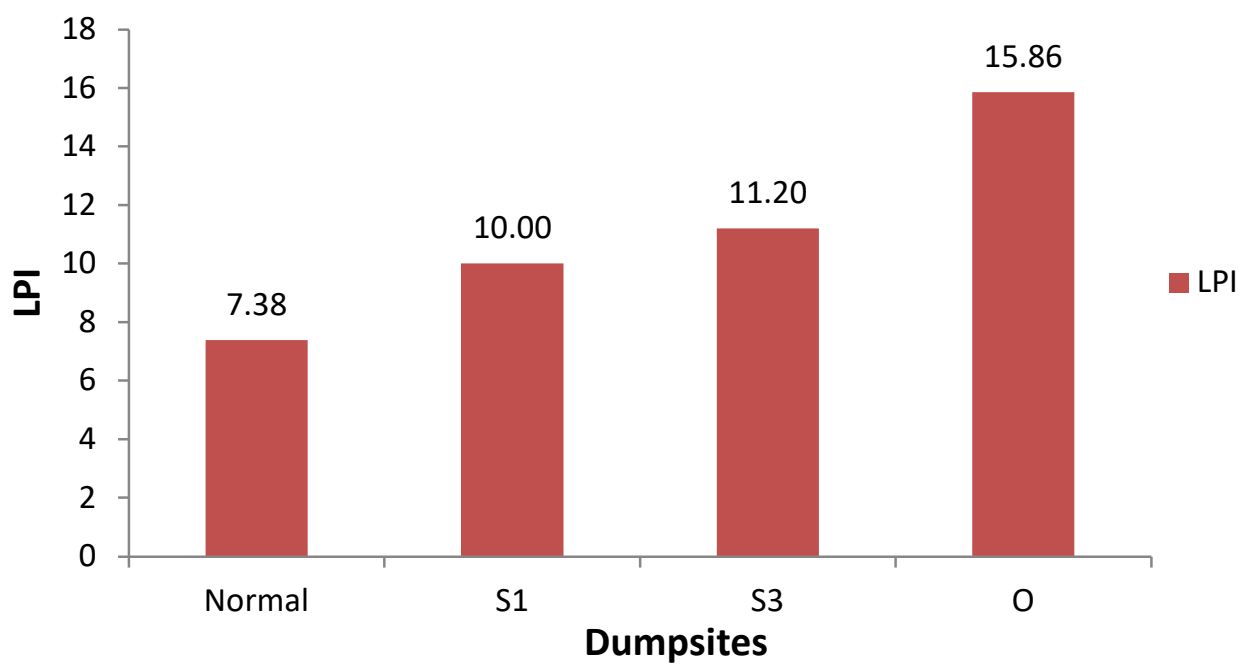

Figure 5: Leachate Pollution Index (LPI) of the dumpsites 


\section{CONCLUSION}

High $\mathrm{BOD}_{5}$ and $\mathrm{COD}$ value of Orile and Solous 3 dumpsites leachates indicated that both dumpsites are in their acid anaerobic phase which is characterized by low value of $\mathrm{pH}$ and high risk of metal leaching whereas the $\mathrm{BOD}_{5}$ and $\mathrm{COD}$ value of Solous 1 dumpsite leachate revealed that it is at methane phase which is characterized by high value of $\mathrm{pH}$, emission of gas, low risk of metal leaching and low decomposition of organic compounds.

The study showed that Leachate from Orile dumpsite has a biodegradability value higher than Leachate from Solous 3 and Solous 1 dumpsites. This implies that biodegradability of a dumpsite increases with age, as shown in the leachates of the dumpsites of various ages considered.

Furthermore, the study also revealed that Leachate Pollution Index of younger dumpsites was higher than older ones. This indicates that younger dumpsite leachate has higher pollution potential than older dumpsite leachate.

It can also be deduced that Orile dumpsite which has high Leachate Pollution Index and biodegradability value poses more danger to groundwater quality than Solous 3 and Solous 1. A liner is therefore recommended to mitigate its negative impact on the groundwater quality.

\section{References}

Adewole, A. T. (2009) Waste Management towards Sustainable Development in Nigeria. A case study of Lagos State. International Non-Governmental Organization Journal 4(4):173-179.

Barjinder, B., Sani, M. S., and Jha, M.K. (2013) Characterization of Leachate from Municipal Solid Waste (MSW) landfill site in Ladlians, India: A comparative study. International Journal of Engineering Research and Applications (IJERA) (2): 732-745

Barlaz, M. A., Ham, R. K., and Shaefer, D. M. (1990) Methane Production from municipal refuse: A Review of Enhancement Techniques and Microbial Dynamics. Rev. Environ. Contr. 19, 6, 55.

Chain, E. S. K. and Dewalle, F. B. (1976) Sanitary Landfill Leachate and Direct Treatment, Journal of Environmental Engineering Division, 102 (2) 411-431.

Clark, J. (2006). Rivers and the Catchment: Impact of Landfill on Water Quality. Earth Science Branch, Scottish Natural Heritage.

Daskalopoulos, E. Bard, O. and Robert, S. D. (1998). Municipal Solid: a prediction methodology for the generation rate and composition in the European Union Countries and the United States of America. Resources Conservation and Recycling (24): 155-166.

Dauda, M. and Osita O. O. (2003) Solid Waste Management and re-use in Maiduguri, Nigeria towards the Millennium Development Goals. 29 WEDC International Conference, Abuja, Nigeria pp. 20-23.

Dawudu, M. O., Paiyeda, A. (2007) Evaluation of Groundwater and Stream Quality Characteristics in the Vicinity of a Butter Factory in Ibadan, Nigeria. Applied Sci. (2): 1071-1076.

Deng, Y. and Englehardt, J. D. (2006) Treatment of Landfill Leachate by Fentron Process: Water Research 40(20) 3683-3694.

El-Fadel, M., Findikakis, A. N. and Leckie, J. O. (1995) Environmental Impact of Solid Waste Landfilling, Journal of Environmental Management

Farquherr, G. J. and Rover, F. A. (1983) Gas Production During Refuse Decomposition. Water, soil and air pollution (2): 483-495. 
Volume 4, Issue 1; March, 2020.

Kumar, D. and Allapat B. J (2005). Evaluating Leachate contamination potential of Landfill Sites using Leachate Pollution Index. Clean Technologies and Environmental Policiy, 7 (3): 190 197.

LAWMA. Lagos State Waste Management Authority (2011) Integrated Waste Management, Shifting the Paradyne. Proceedings of 47th Annual International Conference of the Nigerian Geosciences Society (NMGS): P. 110. (www.lawma.gov.ng).

Li, X. Z. and Zhao, Q. L. (2002) Map Precipitation from Landfill Leachate and Seawater, bitter water. Environmental Technology 23 (9): 989-1000

Longe, E. O. and Balogun, M. R. (2010) Groundwater Quality Assessment near Municipal Dumpsite, Lagos. Research journal of Applied Science, vol (2): 39-44.

Ohman, C. (1991) OmvandlingsfaseriettKommunaltavfallsupplag.ivl report B1017 (In Sweddish)

Ostman, M., Wahlbeg, O., Agren, S., and martesson, A. (2006) Metal and Organic Content in a combined household and Industrial landfill, Waste Management pp. 142-150

Perrson, I. (1996) MikrobiologiskaochKemiska processor. In Deponering AFRkompendum 5 editor Hogland, W, Sweedish Environmental Protection Agency ISSN1402-0210 stockholm (In Sweddish)

Qasim, S. R. and Chiang, W. (1994) Sanitary Landfill Leachate Generation Control and Treatment. (Lancaster, PA. Tecomic publication)

Sia-Su, G. L. (2008). Assessing the Effect of Dumpsite to Groundwater Quality in Payatas, Philipines. American Journal of Environment Sci., 4(4): 276-280

Zainol, N. A., Abdul, A. H. and Yusoff, Ms (2012) Characterization of Leachate from Kuala Sepelang and Kulim Landfills: A comparative study. Energy and Environment Research 2(2): $45-52$ 